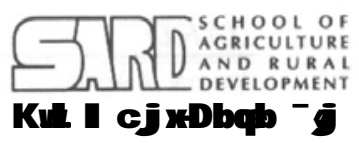

Available online at http://www.banglajol.info/index.php/jard

\title{
Measurement and Analysis of Total Factor Productivity Growth in Modern Variety Potato
}

\author{
M. A. BASET ${ }^{1 *}$, M. R. KARIM ${ }^{2}$ \& M. AKTER ${ }^{3}$ \\ ${ }^{1}$ Agricultural Economics Division, Bangladesh Agricultural Research Institute, Joydebpur, Gazipur, \\ Bangladesh \\ ${ }^{2 \& 3}$ Agricultural Economics Division, Bangladesh Agricultural Research Institute, Joydebpur, \\ Gazipur, Bangladesh
}

\begin{abstract}
The study dealt with the whole scenario of modern variety potato production in Bangladesh covering the period from 1980-81 to 2005-06. The study estimated the extent of shift of production function or the supply curve of modern variety of potato in Bangladesh. The total factor productivity index was estimated using the Tornqvist-Theil index formulation. The growth rate of area, production and yield were found increasing steadily from the year 1980-81. A substantial change has been started from the year 1998-99. The trend of inputs used was found increasing. Almost all the partial as well as the input, output and total factor productivity indices were also found increasing. It may be concluded that for sustaining the present growth of modern variety potato production, the development of new varieties of potato and extensive extension works are needed.
\end{abstract}

Key words: Growth rate, partial factor productivity, total factor productivity, modern variety potato.

\section{INTRODUCTION}

Potato is the leading vegetable crop in the world. At least 40 countries used potato as their staple food (Swaminathan et. al., 1982 and Islam, 1987). In Bangladesh, it is one of the most important vegetables and considered as cash crop. It ranks third after rice and wheat. Almost each and every family consumes potato as vegetable year round in Bangladesh. Both acreage and production of potato are found increasing day by day in the country. But if we look at the productivity it was found not highly encouraging as the modern variety introduction in the country. In the last two consecutive decades there has been tremendous growth both in acreage and production of modern variety potato. Now this is the right time to analyze the factors of productivity for whole scenario of modern variety potato by disaggregating into three sub-periods i.e. a) $1980-81$ to $1989-90$, b) $1990-91$ to 1999-00 and 2001-02 to 2005-06.

In light of the fact that the present study was undertaken to identify the factor of productivity, to estimate the input used in modern variety of potato production, to estimate the partial as well as total factors productivity indices and finally to provide some policy guidelines for scientists, extension personnel and policy makers.

* Corresponding author: PSO, Agril. Econ. Div., BARI, Joydebpur, Gazipur-1701, Tel.: 02-9252731, E-mail: drbasetecon@yahoo.com

(C) 2009 School of Agriculture and Rural Development, Bangladesh Open University, All rights reserved. 


\section{A. Baset et al.}

\section{Materials And Methods}

Total factor productivity (TFP) analysis is the extension of the partial factor productivity analysis (PFP). Its nature is non-frontier non parametric analysis (Grosskopf, 1993). There are three types of measurement of total factor productivity (Christensen, 1975). The first one is called arithmetic measurement, the second is called geometric measurement while the latest and the most widely used measurement developed by Tornqvist-Theil in 1976 popular with the name Divisia index or Tornqvist Divisia index or Tornqvist-Theil index in most of the literatures (Diewert 1976). This formula was used by Rosegrant et. al. (1992) in their measurement of TFP in Indian agriculture. However, it is one kind of ex-post type of analysis. In other words, it is known as inter-temporal analysis. The Tornqvist Divisia index formulation was used for the analysis of the present study on modern variety potato. The technique was as follows:

Total Output Index (TOI)

$\mathrm{TOI}_{\mathrm{t}} / \mathrm{TOI}_{\mathrm{t}-1}=\prod_{\mathrm{j}}\left(\mathrm{Q}_{\mathrm{j}} / \mathrm{Q}_{\mathrm{jt}-1}\right)^{(\mathrm{Rjt}+\mathrm{Rjt}-1)^{1 / 2}}$

Total Input Index (TII)

$\mathrm{TII}_{\mathrm{t}} / \mathrm{TII}_{\mathrm{t}-1}=\prod_{\mathrm{i}}\left(\mathrm{X}_{\mathrm{it}} / \mathrm{X}_{\mathrm{it}-1}\right)^{(\text {Sit+Sit-1) })^{1 / 2}}$

Total Factor Productivity Index (TFPI)

$\mathrm{TFPI}_{\mathrm{t}}=\left(\mathrm{TOI} / \mathrm{TII} \mathrm{t}_{\mathrm{t}}\right)^{* 100}$

where, $R_{j t}$ is the share of output $j$ in total revenue, $Q_{j t}$ is output $j, S_{i t}$ is the share of input $i$ in total input cost, $X_{i t}$ is input $i$ in all period t. By specifying TOI $\mathrm{t}_{\mathrm{t}-1}$ and $\mathrm{TII}_{\mathrm{t}-1}$ equal to 100 in the initial year. The above equations provide the total output, total input and total factor productivity indices for the specified period t. The indices were estimated considering the base year 1980-81=100. All the inputs and output were computed based on the current prices. Our intension was to analyze the whole scenario of modern variety potato covering the period from 1980-81 to 2005-06.

\section{Data sources and estimation}

The time series data on both inputs and outputs were needed to estimate the total factor productivity index. The production data on output and area were obtained from Bangladesh Bureau of Statistical (BBS) year books of 1984-85, 1994-95 and 2005-06. But, the yearly data on cost of production of potato in both physical and monetary terms were not readily available. It was very difficult to estimate all the inputs in both physical and monetary term. For estimating these data, the first step was to collect the relevant information on physical quantity of inputs from various published sources e.g. Journals, Annual reports and Thesis. The second step was to collect the price data on various inputs from the Bangladesh Bureau of Statistical (BBS) year book and Department of Agricultural Marketing (DAM). Besides, certain statistical techniques were used to interpolate and extrapolate the inputs data. Having all the information, the aggregation of total output and inputs in quantities and monetary terms were estimated for the estimation of total factor productivity index of modern variety of potato.

\section{Results AND Discussion}

This section deals with the growth rates of acreage, production, yield, inputs used and research and extension cost. Subsequently, the total output and input indices and also the total factor productivity indices in three sub-periods i.e. a) $1980-81$ to $1989-90$, b) $1990-91$ to $1999-00$ and 2001-02 to 2005-06 for modern variety of potato were presented.

\section{Growth rates of acreage, production and yield}

Comparing the growth rates of acreage, production and yield for three sub-periods, all of the parameters were found significantly different from zero. In period 1980-81 to 1989-90, the growth rates were found lowest while highest rates were observed in the period 2001-02 to 2005-06. This 
was only due to the technological breakthrough started in the production of modern variety potato at the beginning of the year 1990 onward (Table 1).

Table 1. Annual growth rates of acreage, production and yield of modern variety of potato during the period from 1980-81-2005-06.

\begin{tabular}{l|c|c|c}
\hline Period & Acreages & Production & Yield \\
\hline $1980-90$ & $3.0^{\star \star \star}$ & $2.3^{\star}$ & $-0.6 \mathrm{~ns}$ \\
$1991-00$ & $6.9^{\star \star \star}$ & $8.7^{\star \star \star}$ & $1.8^{\star \star \star}$ \\
$2001-06$ & $13.0^{\star \star \star}$ & $14.5^{\star}$ & $1.5 \mathrm{~ns}$ \\
$1980-06$ & $5.9^{\star \star \star}$ & $7.6^{\star \star \star}$ & $1.6^{\star \star \star}$ \\
\hline
\end{tabular}

*** 0.01 level, ${ }^{* \star} 0.05$ level, ${ }^{*} 0.10$ level and ns=not significant.

\section{Growth rates of inputs used}

Table 2 revealed that the period average inputs used in modern variety potato production in Bangladesh. Majority of the potato farmers of Bangladesh did not use the recommended doses. However, inputs used in potato production were found highest in the period 2000-06 followed by previous period. This was only due to fact that the technological breakthrough was started from the mid eighties and farmers were adopted more and more new technologies. Among them, the seed used was found highest followed by human labour. But if we look at the growth rate of inputs used for potato production in the period 2000-06, all the parameters were found positive except cowdung, urea, insecticides and rent. On the contrary, almost all the growth parameters were found highest and significantly positive except cow-dung, insecticide and rent in the period of 1990-99. But, almost all the partial factor productivity indices were found highest in the period 2000-06 (Table 4). This was only due to the higher yield of potato. The inputs indices of human labour, animal power, seed, urea and TSP were found highest in the nineties except cow-dung, MP \& gypsum insecticides, irrigation and rent.

Table 2. Period average inputs used in modern variety of potato production in Bangladesh (per hectare)

\begin{tabular}{ccccccccccc}
\hline Period & $\begin{array}{c}\text { Human } \\
\text { labour }\end{array}$ & $\begin{array}{c}\text { Animal } \\
\text { power }\end{array}$ & Seed & $\begin{array}{c}\text { Cow- } \\
\text { dung }\end{array}$ & Urea & TSP & $\begin{array}{c}\text { MP \& } \\
\text { gyp. }\end{array}$ & Insect. & Irrig. & $\begin{array}{c}\text { Rent } \\
\text { as kg }\end{array}$ \\
\cline { 2 - 11 } & mandays & pairdays & $\mathrm{kg}$ & $\mathrm{kg}$ & $\mathrm{kg}$ & $\mathrm{kg}$ & $\mathrm{kg}$ & litre & hrs & $\mathrm{kg}$ \\
\hline $1980-89$ & 178.20 & 27.35 & 1248.91 & 1184.20 & 184.55 & 121.14 & 216.50 & 3.85 & 37.40 & 430 \\
& $(.58)$ & $(1.48)$ & $(.63)$ & $(.95)$ & $(2.8)$ & $(1.86)$ & $(4.38)$ & $(21.00)$ & $(.15)$ & $(-2.70)$ \\
$1990-99$ & 222.75 & 34.01 & 1472.22 & 1133.92 & 254.33 & 150.99 & 366.15 & 8.68 & 40.20 & 390 \\
& $(2.94)$ & $(1.82)$ & $(2.81)$ & $(-.22)$ & $(1.90)$ & $(1.72)$ & $(1.48)$ & $(-.12)$ & $(1.50)$ & $(-1.76)$ \\
$2000-06$ & 248.42 & 39.44 & 1688.32 & 1026.85 & 283.25 & 177.76 & 413.48 & 6.62 & 42.67 & 340 \\
& $(.55)$ & $(.74)$ & $(1.10)$ & $(-.87)$ & $(-.36)$ & $(3.09)$ & $(.55)$ & $(-2.7)$ & $(2.70)$ & $(-8.11)$ \\
$1980-06$ & 211.54 & 32.70 & 1436.20 & 1128.55 & 234.16 & 145.69 & 319.52 & 635 & 39.69 & 390 \\
& $(1.86)$ & $(2.00)$ & $(1.66)$ & $(-.71)$ & $(2.47)$ & $(2.12)$ & $(3.77)$ & $(5.55)$ & $(.76)$ & $(-1.41)$ \\
\hline
\end{tabular}

Source: Own estimation and figures in bracket indicate growth rates

Table 3. Period average inputs used in modern variety potato production in Bangladesh (000 unit)

\begin{tabular}{cccccccccccc}
\hline Period & $\begin{array}{c}\text { Human } \\
\text { labour }\end{array}$ & $\begin{array}{c}\text { Animal } \\
\text { power }\end{array}$ & Seed & $\begin{array}{c}\text { Cow- } \\
\text { dung }\end{array}$ & Urea & TSP & $\begin{array}{c}\text { MP \& } \\
\text { gyp. }\end{array}$ & Insec. & Irrig. & $\begin{array}{c}\text { Rent } \\
\text { as kg }\end{array}$ \\
\hline Units & mandays & pairdays & $\mathrm{kg}$ & $\mathrm{kg}$ & $\mathrm{kg}$ & $\mathrm{kg}$ & $\mathrm{kg}$ & litre & hrs & $\mathrm{kg}$ \\
\hline $1980-89$ & 11509 & 1769 & 80701 & 76070 & 11986 & 7859 & 2413 & 27 & 2413 & 27570 \\
$1990-99$ & 22135 & 3362 & 146211 & 110543 & 25172 & 14924 & 3960 & 36 & 3960 & 36801 \\
$2000-06$ & 52043 & 8240 & 354420 & 214209 & 58861 & 37666 & 9018 & 69 & 9018 & 61855 \\
$1980-06$ & 24950 & 3875 & 169063 & 121207 & 27875 & 17455 & 4532 & 40 & 4532 & 40737 \\
\hline
\end{tabular}

Source: Own estimation 


\section{A. Baset et al.}

Table 4. Period average partial factor productivity indices of different inputs used in modern variety potato production in Bangladesh

\begin{tabular}{lcccccccccc}
\hline Period & $\begin{array}{c}\text { Human } \\
\text { labour }\end{array}$ & $\begin{array}{c}\text { Animal } \\
\text { power }\end{array}$ & Seed & $\begin{array}{c}\text { Cow- } \\
\text { dung }\end{array}$ & Urea & TSP & $\begin{array}{c}\text { MP \& } \\
\text { gyp. }\end{array}$ & Insect. & Irrig. & Rent \\
\hline $1980-89$ & 97.31 & 101.20 & 93.76 & 111.28 & 83.64 & 84.60 & 95.53 & 112.52 & 95.53 & 111.36 \\
$1990-99$ & 89.48 & 92.65 & 90.92 & 132.72 & 68.68 & 77.26 & 101.57 & 141.88 & 101.57 & 140.96 \\
$2000-06$ & 97.21 & 97.49 & 96.64 & 178.63 & 75.37 & 80.05 & 116.71 & 197.80 & 116.71 & 196.11 \\
$1980-06$ & 94.27 & 97.06 & 93.33 & 135.07 & 75.98 & 80.73 & 102.74 & 143.49 & 102.74 & 142.30 \\
\hline
\end{tabular}

Source: Own estimation

In Table 5, the growth rate of research and extension was found high and significant at $1 \%$ level. Tuber Crops Research Centre (TCRC) of Bangladesh Agricultural Research Institute (BARI) contributed a lot for the development of a number of new varieties. But the growth rate of extension was higher than that of research. But the technological breakthrough was not only the preconditions to produce more potato it was also necessary to conduct research to the development of new varieties of potato.

Table 5. Annual growth rates of research and extension investment for potato improvement from 1980 to 2006.

\begin{tabular}{lccccc}
\hline Period & TCRC/BARI & BARC & CIP & Extension & Research \\
\cline { 2 - 6 } & 1 & 2 & 3 & 4 & $(1+2+3)$ \\
\hline $1980-2006$ & $8.20^{\star \star \star}$ & $4.52^{\star \star}$ & $4.64^{\star \star \star}$ & $13.84^{\star \star \star}$ & $6.17^{\star \star \star}$ \\
\hline
\end{tabular}

Source: TCRC/BARI, BARC and DAE, *** 0.01 level

\section{Growth rates of output, input and TFPI indices}

The annual average growth rates in the total output index (TOI), total input index (TII) and total factor productivity index (TFPI) shown in Table 6. The results estimated for individual years appeared to vary widely (Table 7) because of fluctuation in the prices of input and output. The TOI growth rate was found highest in the period of 2001-2006 but TFPI growth rate was found highest in the period 1991-2000. It indicated that the lion share of profits was received by the potato farmers. In other words, higher the TFPI growth rates higher the efficiency meaning that the farmers were more benefited than that of consumers. It indicated that the farmers were more aware to produce commercially the modern variety of potato using the available potato technologies.

Table 6. Annual growth rates of output, inputs and TFPI indices of modern variety potato production from 1980 to 2006.

\begin{tabular}{lccc}
\hline Period & TOI & TII & TFPI \\
\hline $1981-90$ & $7.49^{\star \star \star}$ & $2.01^{\star}$ & $3.90^{\star}$ \\
$1991-00$ & $11.3^{\star \star \star}$ & $7.39^{\star \star \star}$ & $5.40^{\star \star \star}$ \\
$2001-06$ & $15.00^{\star \star}$ & $10.01^{\star}$ & $4.55^{\star \star \star}$ \\
$1981-06$ & $7.86^{\star \star \star}$ & $3.68^{\star \star}$ & $4.18^{\star \star \star}$ \\
\hline
\end{tabular}

*** 0.01 level, ${ }^{\star \star} 0.05$ level, * 0.10 level and ns=not significant.

Table 7 revealed that the trend of both TII and TOI were found increasing, but the rate was found higher in TOI than that of TII. As a result, TFPI was increasing over the year with the exception in the year of 1982-83 and 1983-84. This was only due to the fact the farmers did not adopt primarily the modern varieties of potato. Moreover the total factor productivity index (TFPI) of modern variety of potato production increased steadily due to the technological progress. In addition, increase in productivity can be induced by giving more attention in the prices of input and output compare to that of research and extension. 
Table 7. Annual indices of total input, total output and total factor productivity from 1981-82 to 2005-06.

\begin{tabular}{lccc}
\hline Year & TII & TOI & TFPI \\
\hline $1981-82$ & 100.00 & 100.00 & 100.00 \\
$1982-83$ & 118.81 & 83.16 & 69.99 \\
$1983-84$ & 122.09 & 73.82 & 60.47 \\
$1984-85$ & 141.95 & 161.53 & 113.79 \\
$1985-86$ & 151.64 & 152.56 & 100.60 \\
$1986-87$ & 158.30 & 178.42 & 112.71 \\
$1987-88$ & 172.60 & 152.92 & 88.59 \\
$1988-89$ & 190.74 & 188.26 & 98.70 \\
$1989-90$ & 193.29 & 229.39 & 118.68 \\
$1990-91$ & 193.43 & 216.12 & 111.73 \\
$1991-92$ & 217.88 & 225.78 & 103.62 \\
$1992-93$ & 250.80 & 265.55 & 105.88 \\
$1993-94$ & 269.94 & 320.59 & 118.77 \\
$1994-95$ & 252.01 & 309.38 & 122.76 \\
$1995-96$ & 218.71 & 281.87 & 128.88 \\
$1996-97$ & 290.14 & 363.28 & 125.21 \\
$1997-98$ & 286.63 & 406.94 & 141.97 \\
$1998-99$ & 242.34 & 347.32 & 143.32 \\
$1999-00$ & 249.71 & 407.04 & 163.01 \\
$2000-01$ & 311.99 & 543.35 & 174.16 \\
$2001-02$ & 244.90 & 442.90 & 180.85 \\
$2002-03$ & 186.44 & 360.34 & 193.28 \\
$2003-04$ & 208.51 & 423.18 & 202.96 \\
$2004-05$ & 323.02 & 706.29 & 218.65 \\
$2005-06$ & 331.92 & 742.23 & 223.62 \\
\hline Average & 217.11 & 307.29 & 132.89 \\
\hline
\end{tabular}

Source: Own estimation

\section{Conclusions And Policy Implication}

The change in yield is a sufficient indicator of productivity. The land productivity can be improved by costly investments that may not fully compensate for the increase in yield. The total factor productivity index is a necessary and sufficient indicator for changes in productivity. But, the present total factor productivity indices of potato were found increasing but the rate was found moderate and satisfactory. This finding was further confirmed by the partial factor productivity indices. All of these factor productivity indices were found encouraging. On an average, the technological change in modern variety potato production during the past period was mostly cost effective for the farmers. In view of these, a) the potato scientist should give effort to break the present yield ceiling of potato by developing high yielding new varieties, b) the Government should give more attention to allocate sufficient fund for further development of potato, c) Policy makers should give attention to minimize inputs price and maximize the output price by any means and d) the extension personnel should be encouraged to increase potato acreage.

\section{Literature Cited}

Bangladesh Bureau of Statistics (BBS). 1984-85. Ministry of Planning. Government of the People's Republic of Bangladesh.

Bangladesh Bureau of Statistics (BBS). 1994-95. Ministry of Planning. Government of the People's Republic of Bangladesh. 
Bangladesh Bureau of Statistics (BBS). 2005-06. Ministry of Planning. Government of the People's Republic of Bangladesh.

Christensen, L.R. 1975. Concepts and Measurement of agricultural Productivity. American Journal of Agricultural Economics. 57(5), 910-915.

Diewert, W.E. 1976. Exact and Superlative Index Numbers. Journal of Econometrics. 4, 115-145.

Grosskopf, S. 1993. Efficiency and Productivity.In: The Measurement of Productivity Efficiency (eds O.H.Fried, C.A.K.Lovell \& S.S. Schimdt), 160-194. Oxford University Press, New York.

Islam, M. T. 1987. An Economic Study on Potato Preservation in Cold Storage in Some Selected Areas of Bangladesh. Unpublished Master's Thesis. Department of Cooperation and Marketing, Bangladesh Agricultural University.

Rosegrant, M.W. and Evenson, R.E.1992. The Contribution of Agricultural Research System to Agricultural Production in India. Indian journal of Agricultural Economics. 28(4), 212-230.

Swaminathan, M. S. and Sawer, R. I. 1982. The Potential of the Potato as a World Food Proceeding International Congress Research for the Potato in the year 2000" Tenth Anniversary 1972-1982. International Potato Centre (CIP).

\section{Appendices}

Table 1. Total input cost used in modern variety of potato in Bangladesh

\begin{tabular}{|c|c|c|c|c|c|c|c|c|c|c|c|}
\hline Year & $\begin{array}{c}\text { Human } \\
\text { labour } \\
(000 \mathrm{tk})\end{array}$ & $\begin{array}{c}\text { Animal } \\
\text { power } \\
(000 \mathrm{tk})\end{array}$ & $\begin{array}{c}\text { Seed } \\
(000 \mathrm{tk})\end{array}$ & $\begin{array}{c}\text { Cow- } \\
\text { dung } \\
(000 \mathrm{tk})\end{array}$ & $\begin{array}{c}\text { Urea } \\
\text { (000 tk) }\end{array}$ & $\begin{array}{c}\text { TSP } \\
(000 \mathrm{tk})\end{array}$ & $\begin{array}{c}\text { MP \& } \\
\text { gyp. } \\
\text { (000 tk) }\end{array}$ & $\begin{array}{l}\text { Insect. } \\
\text { (000 tk) }\end{array}$ & $\begin{array}{c}\text { Irrig. } \\
\text { (000 tk) }\end{array}$ & $\begin{array}{c}\text { Rent } \\
(000 \text { tk) }\end{array}$ & $\begin{array}{c}\text { Total } \\
(000 \mathrm{tk})\end{array}$ \\
\hline 80-81 & 121105 & 29809 & 234236 & 6578 & 21188 & 2 & 35665 & 9 & 52 & 40 & 592 \\
\hline & & & & & & & & & & & \\
\hline-83 & 189675 & 44387 & 379910 & 8863 & 38767 & 26653 & 72143 & 12361 & 1898 & 5228 & 9885 \\
\hline & & 50951 & 459395 & 565 & 48393 & & 85149 & & 120612 & 46235 & 92006 \\
\hline & 303690 & 65 & 437079 & 9475 & 66029 & 42248 & 118123 & & 151242 & 57976 & \\
\hline-86 & 328759 & 87195 & 366163 & 9394 & 62171 & 38797 & 111311 & 25532 & 172010 & 65937 & 1267269 \\
\hline & & 369 & 33 & 2222 & 21 & 28 & 116574 & & & 79226 & 182 \\
\hline & & & & & 07 & & & & & & \\
\hline & & & & & & & 114808 & & 21 & 53 & \\
\hline & & 91997 & 65 & 31 & & & & & & 698 & \\
\hline & & 681 & 77 & & & & 30 & & & & \\
\hline & & & & & 10 & 0 & 20 & & & 33 & \\
\hline & & & 985 & & & 32 & 90 & & & 67 & \\
\hline & & & & & & & & & & & \\
\hline & & & 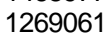 & & & & 60 & & & 89 & 84 \\
\hline & & & 38 & 16 & 12 & 6968 & 88 & 20 & & 25 & 69 \\
\hline & & & & & & & & & & & \\
\hline & & & & & & & & & & 68 & \\
\hline & & & & & & & 663 & & & & \\
\hline & & & & & & 6136 & 638 & & & & 89 \\
\hline & & & & 4963 & 26 & 72 & 671102 & 425024 & 02094 & 36 & 809 \\
\hline & & & & & & & & & & & \\
\hline & & & & & & & 97 & & & 66 & 98 \\
\hline & 92 & 873257 & 712 & 57597 & 350285 & 418209 & 848261 & 486388 & 889061 & 340807 & 14976097 \\
\hline & & & & & & & & & & & \\
\hline 20 & 40 & 26 & 1920 & 91087 & 47 & 30 & 11 & & 15557 & & 478 \\
\hline \multicolumn{12}{|c|}{ Following are the averages of the period from 1980 to 2006,1980 to 1989,1990 to 1999 and 2000 to 2006 respectively } \\
\hline & & & & & & & & & & & \\
\hline & & & & & & & & & & & \\
\hline & 909180 & 211161 & 1702 & $22 \varepsilon$ & 144 & 166703 & 343302 & 211280 & 18 & 156713 & 63 \\
\hline 织 & 3903715 & & 7311970 & & & & & 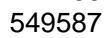 & & & 5962843 \\
\hline
\end{tabular}

Sources: BBS, BARI annual report (2006-07), TCRC report, Krishi Diary of different years and journals 
Table 2. Acreage, production, yield and harvest price of MV potato in Bangladesh

\begin{tabular}{ccccc}
\hline Year & $\begin{array}{c}\text { Area } \\
\text { (ha) }\end{array}$ & $\begin{array}{c}\text { Production } \\
\text { (ton) }\end{array}$ & $\begin{array}{c}\text { Yield } \\
\text { (ton/ha) }\end{array}$ & $\begin{array}{c}\text { Harvest price } \\
\text { (tk/ton) }\end{array}$ \\
\hline $1980-81$ & 50993.93 & 590400.00 & 11.58 & 1520.77 \\
$1981-82$ & 56275.30 & 680615.00 & 12.09 & 1210.61 \\
$19882-83$ & 61803.64 & 745064.00 & 12.06 & 1078.20 \\
$1983-84$ & 64251.01 & 793681.00 & 12.35 & 2302.40 \\
$1984-85$ & 67139.68 & 802500.00 & 11.95 & 2247.28 \\
$1985-86$ & 65466.40 & 763505.00 & 11.66 & 2693.59 \\
$1986-87$ & 65627.53 & 767450.00 & 11.69 & 2302.40 \\
$1987-88$ & 77653.85 & 936935.00 & 12.07 & 2747.28 \\
$1988-89$ & 65452.23 & 778989.00 & 11.90 & 3393.59 \\
$1989-90$ & 69649.80 & 737525.00 & 10.59 & 3593.59 \\
$1990-91$ & 76305.67 & 893860.00 & 11.71 & 3393.59 \\
$1991-92$ & 80823.89 & 1049725.00 & 12.99 & 3600.00 \\
$1992-93$ & 82485.83 & 1063040.00 & 12.89 & 4380.00 \\
$1993-94$ & 84307.69 & 1120120.00 & 13.29 & 4100.00 \\
$1994-95$ & 84892.71 & 1151140.00 & 13.56 & 3660.00 \\
$1995-96$ & 85251.01 & 1175195.00 & 13.79 & 4640.00 \\
$1996-97$ & 86364.37 & 1187720.00 & 13.75 & 5210.00 \\
$1997-98$ & 88439.27 & 1229190.00 & 13.90 & 4400.00 \\
$1998-99$ & 154611.34 & 2126850.00 & 13.76 & 5210.00 \\
$1999-00$ & 155987.85 & 2335390.00 & 14.97 & 6390.00 \\
$2000-01$ & 162408.91 & 2600630.00 & 16.01 & 4870.00 \\
$2001-02$ & 163763.16 & 2462140.00 & 15.03 & 4220.00 \\
$2002-03$ & 169141.70 & 2832090.00 & 16.74 & 4450.00 \\
$2003-04$ & 189921.05 & 3298630.00 & 17.37 & 7160.00 \\
$2004-05$ & 290160.00 & 4996320.00 & 17.22 & 7589.60 \\
$2005-06$ & 279750.00 & 4562800.00 & 16.31 & 8044.98 \\
\hline
\end{tabular}

Sources: BBS, BARI annual report (2006-07), TCRC report, Krishi Diary of different years and journals 